\title{
CHINA'S NEW “GREEN POLICY” OF SUSTAINABLE MOBILITY AND DEVELOPMENT (DECARBONIZATION IN CHINA AND WITHIN BELT AND ROAD INITIATIVE)
}

\author{
M. Smotrytska, \\ $\mathrm{PhD}$ of International Politics, \\ School of Politics and International Studies, \\ Central China Normal University, \\ Wuhan, Hubei province, the P.R. China; \\ Research Fellow, \\ International Institute for Middle East and Balkan Studies \\ Department for Strategic Studies on Asia, \\ Vienna, Austria \\ SmotrM_S@mail.ru \\ Smotr.m.s@gmail.com
}

The aim of the article is to examine the practical transformations initiated by the leadership of the PRC in connection with the implementation of the concepts of "One Belt - One Road" initiative (BRI) and "Ecological Nation".

The scientific novelty of the study is determined by the fact that it attempts to review a new China's "green policy" of sustainable mobility and development in the context of the revival of the new "Silk Road diplomacy", as a consequence and at the same time as one of the reasons for the changes taking place in the modern system of international relations.

The theoretical and methodological basis of the study was made up of both general theoretical and methodological levels of scientific research. A review of documents aimed at increasing the environmental responsibility of Chinese companies in the implementation of BRI projects is made. They reflect modern scientific approaches to ensuring the ecological balance. Environmental risks for projects on the territory of Eurasia, caused by the imperfection of environmental institutions, are considered.

Author uses descriptive case study research method to analyse the possible ways to solve the fundamental problem, emphasizing the importance of Eurasia and transport logistics through it. The article provides an overview of potential $\mathrm{CO}^{2}$ mitigation targets for international railway and maritime transport. The main problems and opportunities of railway roads, Southern warm congested waters are considered. Special attention is paid to the development of Northern waters transhipment lines between China and OECD markets.

The study geared towards investigating the issues that affects BRI states in full cooperation with China within initiative and is divided into three main sections, analysing Logistics, Ecological and Political aspects of BRI, as well as Chinese new approach of Green Sustainable Mobility and Development (China's 14th Five-Year Plan).

(C) 2021 M. Smotrytska; Published by the A. Yu. Krymskyi Institute of Oriental Studies, NAS of Ukraine and the Ukrainian Association of Sinologists on behalf of The Chinese Studies. This is an Open Access article distributed under the terms of the Creative Commons Attribution License (https://creativecommons.org/licenses/by-nc-nd/4.0/). 
In conclusions part author elaborated that while thinking on the best ways of the decarbonizing of transport connections between BRI economies, all the existing risks and opportunities (development of Northern transhipment lines) should be considered.

Keywords: China, Decarbonization, Transport, Energy, Logistics, One Belt - One Road.

\section{НОВА «ЗЕЛЕНА ПОЛІТИКА» КИТАЮ В ГАЛУЗІ СТІЙКОЇ МОБІЛЬНОСТІ ТА РОЗВИТКУ (ДЕКАРБОНІЗАЦІЯ В КИТАЇ ТА В РАМКАХ ІНІЦІАТИВИ «ОДИН ПОЯС - ОДИН ШЛЯХ»)}

\section{М. О. Смотрищъка}

Метою статті $є$ розгляд практичних перетворень, ініційованих керівництвом Китайської Народної Республіки у зв'язку з реалізацією концепцій ініціатив «Один Пояс - один Шлях» (BRI) i «Екологічна нація».

Наукова новизна дослідження визначається тим фактом, що в ньому зроблена спроба розглянути нову китайську «зелену політику» стійкої мобільності і розвитку в контексті відродження «дипломатії Шовкового шляху» як наслідок і водночас як одну із причин змін, що відбуваються в сучасній системі міжнародних відносин

Теоретико-методологічну основу дослідження становлять як загальнотеоретичні, так і загальнометодологічні рівні наукових досліджень. Проведено огляд документів, спрямованих на підвищення екологічної відповідальності китайських компаній під час реалізації проєктів BRI. Вони відображають сучасні наукові підходи до забезпечення екологічного балансу. Розглянуто екологічні ризики для проєктів на території Євразії, зумовлені недосконалістю природоохоронних інститутів.

Автор використовує описовий метод дослідження конкретних прикладів для аналізу можливих шляхів вирішення фундаментальної екологічної проблеми, підкреслює важливість Євразії та транспортної логістики через неї. У статті представлений огляд потенційних цілей щодо зниження викидів $\mathrm{CO}_{2}$ для міжнародних залізничних і морських перевезень. Розглянуто основні проблеми та можливості залізничних колій i південних теплих перевантажених вод. Особлива увага приділяється розвитку ліній із транспортування в північних водах між Китаєм і ринками Організації економічного співробітництва та розвитку.

Дослідження спрямоване на вивчення проблем, які зачіпають держави BRI у повній співпраці з Китаєм у рамках ініціативи, і містить три основні розділи, у яких аналізуються логістичні, екологічні та політичні аспекти BRI, а також новий китайський підхід до екологічно чистої стійкої мобільності та розвитку (14-й п’ятирічний план Китаю).

У заключній частині автор підкреслює, що до прийняття нової траєкторії декарбонізації простежувалася підтримка Китаєм проєктів в області викопного палива, що мала значні негативні екологічні та соціальні наслідки у країнах ініціативи. Вплив пандемії на розвиток китайської інвестиційної й економічної політики показав, що зараз у Китайській Народній Республіці немає альтернативи зеленій траєкторії свого подальшого розвитку. Саме через це, розмірковуючи про найкращі способи декарбонізації транспортних з'єднань між країнами BRI, країна зважає на всі наявні ризики i можливості (розвиток північних ліній перевалки).

Ключові слова: Китай, декарбонізація, транспорт, енергетика, логістика, «Один Пояс - один Шлях».

Розпочата у 2013 р. китайська ініціатива «Один Пояс - один Шлях» (далі BRI (від англ. Belt \& Road Initiative) зі створення глобальної транспортної й інвестиційної інфраструктури об'єднує два (можливо, три, якщо врахувати 
можливий Полярний шовковий шлях) проєкти - Економічний пояс Шовкового шляху і Морський шовковий шлях XXI ст. [Smotrytska 2020a]. Цей проєкт iз формування єдиного Євразійського торговельно-економічного простору i трансконтинентального транспортного коридору включає в себе безліч інфраструктурних проєктів, які в кінцевому підсумку повинні охопити всю планету. Ініціатива зі створення всесвітньої системи транспортних коридорів, що 3’єднують Австралію й Індонезію, усю Центральну та Східну Азію, Близький Схід, Свропу, Африку та через Латинську Америку, у майбутньому може наблизити Китайську Народну Республіку (далі - КНР) до Сполучених Штатів Америки (через Латинську Америку (можливе транспортне сполучення через Доріан Геп) або підводний тунель через Берингову протоку між американською Аляскою і Далеким Сходом Росії).

\section{Логістичний аспект}

Відповідно до авторів проєкту, BRI суттєво скорочує терміни доставки товарів з Китаю в Свропу. Нині середній термін доставки контейнерних вантажів морським транспортом становить 45-60 днів. У разі успішної реалізації проєкту BRI товари з Китаю до Свропи будуть доставлені за 10 днів [Smotrytska 2021].

Варто зазначити, що сухопутні залізниці були обрані як основна експортна галузь, яка могла б стати двигуном ініціативи економічного розвитку КНР. Як i у випадку з японською парадигмою «літаючих гусей», за китайськими залізницями у країни BRI прийдуть постачальники обладнання, програмного забезпечення, інженерних та інших послуг, а також банки, страхові й інші компанії.

У порівнянні перевезень вантажів із Китаю морським і залізничним транспортом час доставки часто $є$ ключовим аргументом на користь залізниці. Водночас дуже часто згадуються 14-15 днів [Bethany 2017], які потрібні для доставки товарів із Китаю в Свропу. На практиці виходить більше: 42-46 днів морським шляхом, 28-32 дні залізничним, 6 днів літаком і 14 днів автомобільним транспортом. Така різниця в чисельності зумовлена необхідністю формування поїзда, затримками на деяких станціях тощо.

Залізничні контейнерні перевезення мають переваги (порівняно з морськими перевезеннями) у таких областях, як: швидкість (терміни), регулярність (ритмічність), надійність (гарантована доставка за розкладом і збереження вантажу) і можливість доставки вантажу в будь-яке місце призначення [Smotrytska 2021].

Аналітики прогнозують, що всі регулярні поїзди з Китаю до Європи через Євразію будуть повністю завантажені в найближчі роки. За оцінками, еластичність попиту на «зручність» (зокрема, оперативність, регулярність і точність доставки) у залізничних контейнерних перевезеннях між Китаєм і Свропою становить 98\%: у 2011-2020 рр. кількість відправлень поїздів на тиждень і обсяг контейнерних перевезень зростали майже однаковими темпами [Vinokurov 2018].

Отже, суворе дотримання залізничних графіків $(99,7 \%$ усіх контейнерних поїздів, що курсують за маршрутами Китай - Свропа, здійснюють свої рейси за розкладом), маючи терміни доставки приблизно втричі менші того, що пропонує морський транспорт, гарантуючи широкий запас «зручності».

Згідно з оцінками, за збереження поточних ставок наскрізних перевезень (зокрема, й китайські субсидії) потенціал зростання контейнерних перевезень Китай - Свропа, створюваний завдяки «зручності» (оперативність, 
регулярність і точність доставки), далеко не вичерпаний. До 2025 р. це може привести до багаторазового збільшення кількості контейнерних поїздів і загального обсягу контейнерних перевезень (до 200 000-250 000 СФЕ (сорокафутовий контейнер)), водночас кількість відправлень поїздів на тиждень (регулярність) збільшиться утричі (приблизно до 100 на тиждень) [Bernadaux 2021].

Хоча загалом негативний вплив залізничного транспорту на навколишне середовище менше, ніж автомобільного, тепловози з дизельними електростанціями чинять негативний вплив на атмосферу, оскільки вихлопні гази містять вуглеводи, оксиди вуглецю, азоту, сірки і різні тверді забруднювачі.

Проте аналіз і оцінка викидів $\mathrm{CO}_{2}$, що безпосередньо виникають у результаті перевезень між Китаєм і Свропейським Союзом (далі - СС) повітряним, морським і залізничним транспортом, припускають, що перевезення двадцятифутових контейнерів (далі - ДФЕ) між Китаєм і СС контейнерним судном призводить до викидів приблизно 0,5 т $\mathrm{CO}_{2}$. Ці викиди можуть знизитися в майбутньому, якщо знизиться середня вартість товарів, що відправляються морем, і якщо це призведе до того, що судна будуть плавати з більш низькою й ефективною швидкістю.

Також передбачалося, що перевезення ДФЕ між Китаєм і СС із використанням дизельних поїздів призведе до викидів приблизно 0,7 т $\mathrm{CO}_{2}$. Однак викиди від електропоїздів могли б бути нижчими, можливо, навіть впасти до нуля, якби вони живилися цілком від поновлюваних джерел [Bernadaux 2021]. Згодом це може стати можливим, якщо електрифікація і використання відновлюваних джерел енергії стануть більш масштабними [Smotrytska 2021]. Однак це буде залежати передусім від забезпечення електрифікації на всіх маршрутах, що використовуються торгівлею, пов'язаною із BRI, на залізницях усієї Свразії.

3 іншого боку, можна знайти декілька оцінок середньої вартості за тоннокілометр авіаперевезень. Міністерство з питань навколишнього середовища, продовольства та сільських районів Сполученого Королівства опублікувало (2012 р.) оцінки того, що авіаперевезення на далекомагістральних рейсах призводять до викидів 630 грамів $\mathrm{CO}_{2}$ на тонно-кілометр [DEFRA 2012]. Це означає, що п’ять тон вантажних авіаперевезень, що пролітають приблизно 8000 кілометрів між Китаєм і СС, призведуть до викидів приблизно 25 т $\mathrm{CO}_{2}$ у порівнянні із приблизно 0,7 т, якщо їх перевозити дизельним поїздом.

Отже, кожен ДФЕ, перенесений із повітря на залізницю, скоротить викиди $\mathrm{CO}_{2}$ майже на 25 тон, а кожен ДФЕ, перенесений із судноплавства на залізницю, може збільшити викиди $\mathrm{CO}_{2}$ не більше ніж на 0,2 т, але може скоротити або усунути викиди $\mathrm{CO}_{2}$, якщо значна частина поїздки буде живитися від поновлюваних джерел енергії. Це говорить про те, що, якщо оцінювати викиди $\mathrm{CO}_{2}$ в результаті перевезень між КНР і Свропою, BRI, імовірно, буде корисна для навколишнього середовища [Smotrytska 2021].

Переведення вантажних перевезень між Китаєм із повітряного транспорту на залізничний має привести до значно нижчих викидів $\mathrm{CO}_{2}$. Це повинно переважити збільшення викидів у результаті перенесення вантажів із моря на залізницю, особливо якщо залізничні перевезення здійснюються завдяки поновлюваним джерелам енергії.

Хоча теоретично здійснення електрифікації залізниць і використання поновлюваних джерел енергії може привести до зниження викидів $\mathrm{CO}_{2}$, можливо, 
навіть до нуля, на практиці цей процес може зайняти десятиліття, що, на жаль, наша планета може не мати. Цей факт змушує людство задуматися про інші можливі способи транспортування, які можуть принести користь як у «зручності» (оперативність, регулярність і точність доставки), так і у зниженні викидів $\mathrm{CO}_{2}$.

Відповідно до Мапи 1, натепер найбільшим вигідною є сухопутна (Зелена) судноплавна лінія. Оскільки морські (теплі води - червоні) транспортні швидкості доставки залишаються досить низькими (зокрема, у сучасних контейнерних суден). Судна, що прямують за маршрутом «Китай - Свропа», розвивають швидкість 20-25 вузлів, тоді як середній загальний час у дорозі, включаючи прохід Суецьким каналом і заходи в порти, становить 35-45 днів. Окрім того, завжди залишається ризик затримок із природних та інших причин (наприклад, очікування завантаження в порту відправлення). Незважаючи на це, регулярність (ритмічність) морських контейнерних перевезень між портами $\mathrm{CC}$ і Китаю досить висока. Наприклад, одна тільки “Maersk Line" здійснює шість рейсів на тиждень. Однак у разі використання морського маршруту для перевезення контейнерів між $С$ і і Китаєм необхідно враховувати не тільки фактичний час у дорозі (4-6 тижнів), але і час, необхідний для консолідації вантажів у портах (приблизно 1 тиждень) [Smotrytska 2021].

Судноплавна лінія теплих вод із Китаю у Грецький порт Пірей для доставки вантажів на Балканський півострів, яка знаходиться на перетині транзитних комунікацій у Європі, Азії й Африці, нині має великі логістичні перспективи. Натепер 80\% вантажів із Китаю в Свропу проходять через Атлантичний океан у порти Північної Свропи [TME 2021]. Судноплавна лінія теплих вод через Аравійське море і Суецький канал на Балкани скорочує час транспортування на 7-10 днів: це поки найкоротший морський шлях із Китаю в Європу (однак для цього Центральній і Східній Свропі необхідно побудувати транспортну інфраструктуру, у якій регіон відчуває величезну потребу. Це особливо актуально для України та країн Балканського півострова, які лише зараз вступають (принаймні Балкани) у період стабільного розвитку після заворушень і воєн, що завдали серйозної шкоди інфраструктурі) [Smotrytska 2020a].

Передбачається, що вантажі, які нині перевозяться морським і повітряним (Біла судноплавна лінія) транспортом між Свропою і Китаєм, у майбутньому перейдуть на залізничні перевезення через поліпшення послуг, що надаються BRI. Вказується, що до 2040 р. приблизно 2,5 млн ДФЕ можуть перейти на залізничний транспорт із морського транспорту і 0,5 млн - 3 повітряного транспорту, що еквівалентно 50-60 додатковим поїздам щодня або 2-3 поїздам на годину в кожному напрямку.

Ці дані показують, що китайські інвестиції в залізничну інфраструктуру привели до того, що залізниця стала життєздатною альтернативою як морю, так і повітрю для торгівлі між Далеким Сходом і Свропою [Smotrytska 2020c].

Що стосується екологічної проблеми, це означає, що морські служби втратять свій найбільш чутливий до часу вантаж на користь залізниці, маючи можливість на практиці плавати повільніше, збільшуючи час транзиту, але знижуючи витрати на паливо, отже, ціни, а також зменшуючи викиди $\mathrm{CO}_{2}$.

Нині, 3 огляду на танення льодів в Північному Льодовитому океані, ми можемо говорити про появу ще однієї альтернативи основним 
трансконтинентальним маршрутам, які проходять через Свразію (Зелена наземна залізнична лінія транспортування, повітряна лінія (Біла) та лінія теплих південних вод Свразії), далі в Африку через Суецький канал (Червона судноплавна лінія) [Bajrektarevic 2010] (див. Мапу 1). Судноплавна лінія холодних вод (блакитна лінія Північних морів, або Арктичний маршрут) дозволить доставляти вантажі в Європу морським шляхом швидше ніж за 48 днів, що в середньому потрібно, для перевезення з північних портів Китаю в Роттердам через Суецький канал, з огляду на те, що прохід вантажного судна з Шанхаю в Гамбург Північним морським шляхом на 2,8 тисячі миль коротше за маршрут через Суецький канал [Smotrytska 2020b] (наприклад, у 2019 р. російський арктичний газовий танкер «Крістоф де Маржері» досяг Південної Кореї з Норвегії без супроводу криголама всього за 15 днів) [Bernadaux 2021].

Окрім критерію часу, судноплавна лінія холодних вод вигідна 3 погляду інших можливостей. Вона зазвичай характеризується як найкоротший морський шлях між Європою і Китаєм, найбезпечніший (наприклад, через проблему сомалійських піратів в Індійському океані), не має обмежень за розміром судна, на відміну від маршруту через Суецький канал (див. Мапу 2). Арктичний маршрут дозволить швидше доставляти вантажі в Свропу морським шляхом, скоротивши маршрут на 20-30\%, отже, буде більш екологічним (завдяки використанню меншої кількості палива і зниженню викидів $\mathrm{CO}_{2}$, економії людських ресурсів) [IOSC 2018].

\section{Енергетична складова частина}

У результаті проведення аналізу співпраці країн в Арктичному регіоні не тільки в галузі транспорту, але і в питаннях, пов'язаних з екологією, можна простежити сприятливі тенденції у вирішенні екологічної проблеми Китаю (отже, BRI у майбутньому). Оскільки нині пріоритетом Китайської Народної Республіки в енергетичному секторі $є$ перехід країни від споживання вугілля до споживання природного газу, пошук стабільних поставок останнього є одним із найважливіших завдань зовнішньої політики Китаю.

Спільний російсько-китайський проєкт «Ямал СПГ» відповідає заявленій меті зниження частки вугілля в загальному споживанні енергії в Китаї до рівня нижче 58\% до кінця 2021 р., оскільки цей проєкт дозволяє диверсифікувати джерела енергії Китаю, сприяє його відмові від вугілля [Yun 2017]. Це знижує викиди $\mathrm{CO}_{2}$ всередині країни і може сприяти впровадженню аналогічної схеми в рамках ініціативи.

Отже, розвиток Північного морського шляху означає економію часу на транспортування вантажів із Китаю в європейські країни, а також можливість вирішення енергетичної проблеми всередині країни (і виходу за їі межі в рамках ініціативи), від вирішення якої, у свою чергу, залежить регулювання екологічного питання.

Коли реалізує Зелену BRI, кожна зі сторін має власні економічні та політичні інтереси. Для Китаю це вирішення серйозних соціальних і екологічних питань і проблем перевиробництва, прагнення встановити більш тісні зв'язки 3 багатими ресурсами країнами, вивести свої товари на європейський ринок [EC 2020]. Концепція BRI вирішує проблему більш раціонального розподілу виробництва і зниження навантаження на навколишнє середовище в Китаї за збереження темпів зростання і посиленні інтеграції із сусідніми країнами і $Є С$. 


\section{Політичний аспект}

Усередині країни вже кілька років Китай намагається створити «екологічну націю», формує суворі екологічні стандарти, обов'язкові для місцевих виробників. Однак, якщо всередині країни Китай стурбований охороною навколишнього середовища, його економічна експансія викликає тривогу в міжнародних екологів. Вони переконані, що китайська сторона таким чином намагається позбутися застарілих, «брудних» технологій, закликають до широкого громадського контролю за будівництвом інфраструктури Шовкового шляху [Егорова 2017].

Вагомий вплив на навколишнє середовище першої хвилі інвестицій BRI уже було зазначено в дослідженні 2018 р., проведеному Китайською радою 3 міжнародного співробітництва в галузі навколишнього середовища і розвитку (CCICED, консультативна рада міжнародних експертів, що працюють з урядом Китаю): низький попит на екологічно чисті стандарти з боку урядів країн, які приймають; складність характеру проєктів і рівень прозорості) [Treyer 2019].

Розуміючи екологічні ризики, які можуть виникнути під час реалізації BRI, китайська сторона вирішила поліпшити логістику i, найголовніше, інструменти реалізації проєктів у країнах-партнерах.

У 2017 р. чотири державні регулювальні органи випустили консультативний документ «Посібник із просування Зеленого поясу і шляху». Це визнало проблеми, з якими стикаються китайські компанії, що здійснюють зарубіжні інфраструктурні проєкти, і закликало їх прийняти більш високі екологічні та соціальні стандарти [ICSC, 2020].

У 2018 р. Китай і Великобританія спільно опублікували принципи зелених інвестицій для «Поясу і Шляху» [Sun 2019]. Ці принципи в основному спрямовані на стандартизацію зеленої логістики у країнах BRI, розширення впровадження зеленої економіки в регіоні i, зрештою, значне скорочення викидів вуглекислого газу в атмосферу.

Другий форум ініціативи «Одного Поясу - одного Шляху» (квітень 2019 р.) доповнив уже затверджені плани озеленення китайської ініціативи. На форумі ухвалено рішення про запуск декількох міжнародних ініціатив у контексті міжнародної коаліції зеленого розвитку BRI і принципів зеленої економіки [Sun 2019].

У листопаді 2019 р. Китайський інститут енергетичних досліджень запропонував ініціативу «2С Азія» (розроблена урядовцями та кліматологами з Японії, Камбоджі, Лаосу, Бутану, Філіппін, Індонезії та Малайзії) для вивчення попиту та пропозиції на енергію в азіатських країнах, а також для роботи над системами декарбонізації та досягнення цілей Паризької угоди [TDS 2019].

Проте, незважаючи на те, що в Паризькій угоді Китай зобов'язався досягти піка викидів вуглецю до 2030 р., через великий економічний вплив Covid-19 країна оголосила, що може відкласти реалізацію нової мети економічного зростання у 2020 р., відображаючи, як ці невизначеності впливають на планування на вищому рівні [Feng 2019]. Економічний спад, спричинений Covid-19, також зумовив стурбованість щодо прихильності Китаю до переходу до низьковуглецевого «зеленого» режиму [Gao 2020].

У результаті взяття вірусу під контроль у межах Китаю уряд вирішив відновити реалізацію попереднього плану. Незабаром після цього, у травні 2020 р. 
[Jingjing... 2020], енергетичне управління Китаю оголосило про проведення громадських консультацій щодо проєкту закону про енергетику, що визначає порядок денний для «зеленого, низьковуглецевого» виробництва та «безпечної й ефективної» енергетичної системи. Варто зазначити, що нині Китай також посідає місце найбільшого у світі виробника й інвестора в екологічно чисту енергетику, хоча вугілля, як і раніше, займає перше місце в енергетичному балансі країни, його частка знижується кожного місяця [Campbell 2019].

Нині міжнародне співтовариство покладає великі надії на те, що тісна китайсько-європейська співпраця в рамках Паризької угоди може привести до більш стандартизованих зобов'язань Китаю, що, імовірно, приведе до значного збільшення зусиль Китаю з розвитку зеленої логістики й економіки [Amelang 2020].

На двосторонньому саміті $С С$ - Китай (червень 2020 р.) усі учасники зобов'язалися розробити «зелені» економічні й інвестиційні стратегії для вирішення як економічної, так і екологічної криз. Дипломатія Р2Р, більш тісне партнерство в області дій щодо вирішення проблеми глобального потепління і поетапного переходу до зеленої економіки Євразії стануть інструментами для реалізації цих стратегій [Waldholz 2020].

У вересні 2020 р. голова КНР Сі Цзіньпін заявив Генеральній Асамблеї $\mathrm{OOH,} \mathrm{що} \mathrm{Китай} \mathrm{досягне} \mathrm{вуглецевої} \mathrm{нейтральності} \mathrm{до} 2060$ р. Пізніше, 12 жовтня, Інститут зміни клімату та сталого розвитку (ICCESD) при Університеті Цінхуа опублікував дослідження про можливий шлях до цієї мети. Так, якщо Китай дотримується рекомендацій доповіді, це може означати більш жорсткі цілі в галузі енергетики та скорочення викидів для 14-го п'ятирічного плану (2021-2025 рр.), більш амбітні внески, визначені на національному рівні (INDCs), на 2030 р. із ще більш швидкою і глибокою декарбонізацією.

Невдовзі п'ятирічний план політики Китаю на вищому рівні в галузі зеленої економіки був названий «одним із найважливіших документів на планеті» для глобального розвитку, що встановлює цільовий показник частки невикопаних видів палива у структурі енергоспоживання [Pamlin 2016].

Згідно із представленою в ньому дорожньою мапою, Китай має намір досягти нульових чистих викидів вуглецю до 2050 р., усі викиди парникових газів знизяться на 90\% порівняно з рівнями 2020 р., якщо він (Китай) хоче досягти вуглецевої нейтральності до 2060 р. Автори не запропонували конкретної дорожньої мапи щодо скорочення викидів протягом 2050-2060 рр., але заявили, що скорочення викидів повинно бути збільшено за негативного зростання викидів в енергетичному секторі і більш інтенсивного зв'язування вуглецю з використанням поглиначів $\mathrm{CO}_{2}$ і технологій декарбонізації китайських підприємств.

Але оскільки економіка й енергетичний сектор є надзвичайно складними системами, зрозуміло, що перехід потребує часу. На першому етапі пріоритетом для досягнення піка викидів вуглецю має бути запобігання додатковим викидам, а не скорочення наявних. Але після 2030 р. темпи скорочення викидів Китаєм «будуть набагато випереджати розвинені країни» [Pamlin 2016].

У процесі проведення аналізу поточного впливу Зеленої BRI дослідники вносять пропозиції щодо економії енергії та скорочення викидів у 2021 фінансовому році, наприклад, 20\% невикопаних видів палива у споживанні 
первинної енергії до 2025 р., водночас граничний рівень викидів вуглецю має становити менше 10,5 млрд т (очікується, що до 2021 р. ці показники становитимуть 16\% і 10,3 млрд т відповідно).

Також рекомендується, щоб Китай посилив і оновив свій INDCs на 2030 p., знизивши викиди вуглекислого газу на одиницю ВВП більш ніж на $65 \%$ порівняно з рівнем 2005 р. і досягнувши $25 \%$ частки невикопаних видів палива у споживанні первинної енергії [Нuахіа 2020].

2021 р. став початком імплементації 14-го п'ятирічного плану Китаю. Офіційно ухвалений 11 березня, він ознаменував собою відхід від орієнтації попередніх планів Пекіна на кількісне зростання. Альтернативою був обраний план, спрямований на втілення більш внутрішньокитайського «нового етапу розвитку», спрямованого на «якісний розвиток».

Варто наголосити на тому, що кількість проєктів, пов'язаних із навколишнім середовищем і зеленим розвитком, становить лише половину проєктів 13го плану. У 14-му плані також не міститься детальної інформації щодо скорочення викидів вуглекислого газу в атмосферу або щодо посилення екологічної політики країни. Проте в ньому наголошується, що норми і стандарти викидів $\mathrm{CO}_{2}$ і виконання зобов'язань Китаю у сфері клімату на 2030 і 2060 рр. відтепер є обов'язком міністерств і адміністрацій провінцій. Це рішення ухвалено з урахуванням впливу пандемії на економіку Китаю. Отже, КНР ще не визначила точну національну траєкторію дій і стратегію зеленого розвитку країни [Grünberg... 2021].

Незважаючи на це, у документі описана більш чітка траєкторія досягнення піка викидів $\mathrm{CO}_{2}$ до 2030 р. і досягнення нейтральності $\mathrm{CO}_{2}$ до 2060 р. На поточний рік уряд оголосив про мету зниження енергоємності приблизно на $3 \%$. Протягом наступних п'яти років влада КНР має намір знизити енергоємність на $13,5 \%$ і вуглецемність на $18 \%$ [Cooper 2021a].

Так, у плані зазначається, що до 2025 р. на невикопані види палива припадатиме 20\% споживання енергії порівняно з 15\% наприкінці 2019 р. [Grünberg... 2021]. Однак, зміцнюючи свою стратегію використання відновлюваних джерел енергії, КНР не повністю відмовилася від використання підходу «чистого вугілля».

\section{Висновки}

Зобов'язання зі скорочення викидів $\mathrm{CO}_{2}$ до 2025 р. показали світові, що КНР поступово рухається до виконання своїх зобов'язань щодо поліпшення клімату (плани на 2030/2060 рр.). Незважаючи на це, 3 огляду на траєкторію зеленого розвитку Китаю, цілком розумно вважати, що нині викиди $\mathrm{CO}_{2}$ в атмосферу будуть рости до 2025 р. [Cooper 2021a]. Ця траєкторія може відкласти важливий прогрес, необхідний для декарбонізації логістики Євразії, до другої половини десятиліття.

Варто розуміти, що зараз (особливо під час глобальної пандемії) Китай продовжує вирішувати завдання щодо задоволення величезних енергетичних потреб своєї економіки, рухаючись у напрямі зеленого розвитку [Сooper 2021b].

Вплив пандемії на розвиток китайської інвестиційної й економічної політики показав, що зараз у КНР немає альтернативи зеленій траєкторії свого розвитку. Якщо Китай почне активно впроваджувати цю зелену стратегію (як усередині країни, так і в рамках ініціативи «Одного Поясу - одного Шляху»), це 
значно знизить економічні витрати (і поліпшить екологічні стандарти) для самої країни і для Євразії загалом. Як приклад зеленої економіки Китай, завдяки зеленій логістиці й інвестиціям, може зробити цю стратегію більш доступною для інших промислово розвинених країн, розташованих уздовж Шовкового шляху [Mathews 2020]. Китайська «стратегія декарбонізації» приведе до євразійської (i, можливо, глобальної) «стратегії декарбонізації», навіть якщо вона частково пов' язана з небезпекою збільшення китайських інвестицій у вугільну енергетику в рамках ініціативи.

До прийняття нової траєкторії декарбонізації можна було бачити, що підтримка Китаєм проєктів в області викопного палива мала значні негативні екологічні та соціальні наслідки у країнах ініціативи «Одного Поясу - одного Шляху». Отже, зміни у проєкті Закону Китаю про енергетику були необхідністю [Mathews 2020]. Вони узгодили (або узгодять) багато інфраструктурних проєктів BRI із загальноприйнятою міжнародною практикою в галузі зеленого розвитку.

3 виходом економіки Китаю виходить 3 пандемії Covid-19 можна очікувати, що вона ще більше зосередиться на цій стратегії зеленого зростання. Навіть більше, у цьому аспекті Китай володіє найважливішими конкурентними перевагами з погляду експорту промислової продукції [Mathews... 2014], перевагами в галузі енергетики, а також безпеки ресурсів і логістики [Jingjing... 2020].

\section{ДОДАТОК}

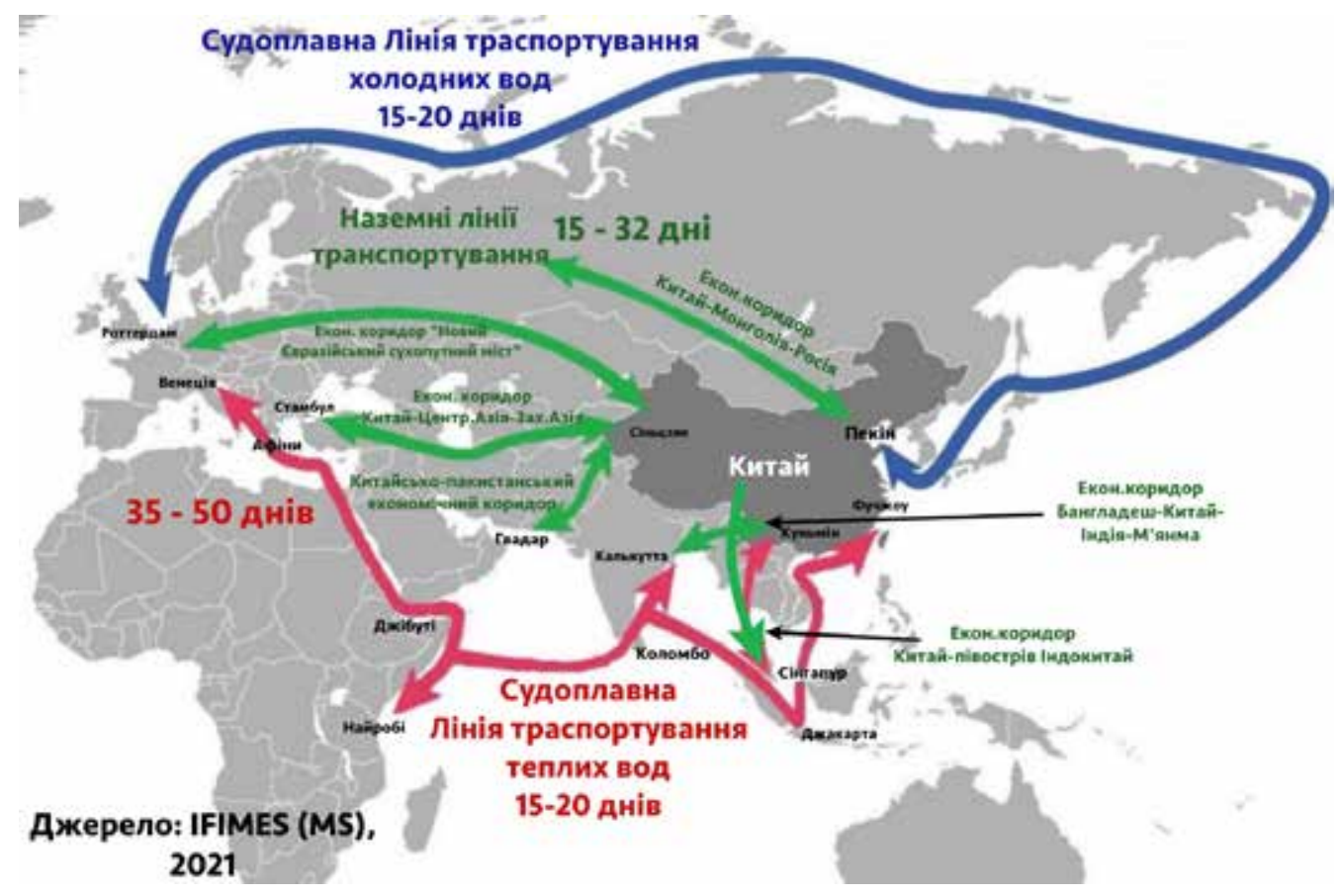

Мапа 1. Лінії транспортування з Далекого Сходу до Західної Європи.

Джерело: створена автором дослідження (Міжнародній інститут IFIMES), 2021 p. 


\section{Криголам : \\ Переваги Північного морського шляху \\ Роттердам - Йокогама - 3,840 нМ. 9,0 днів \\ Роттердам - Шанхай. - 2,361 нМ. 5,5 днів}

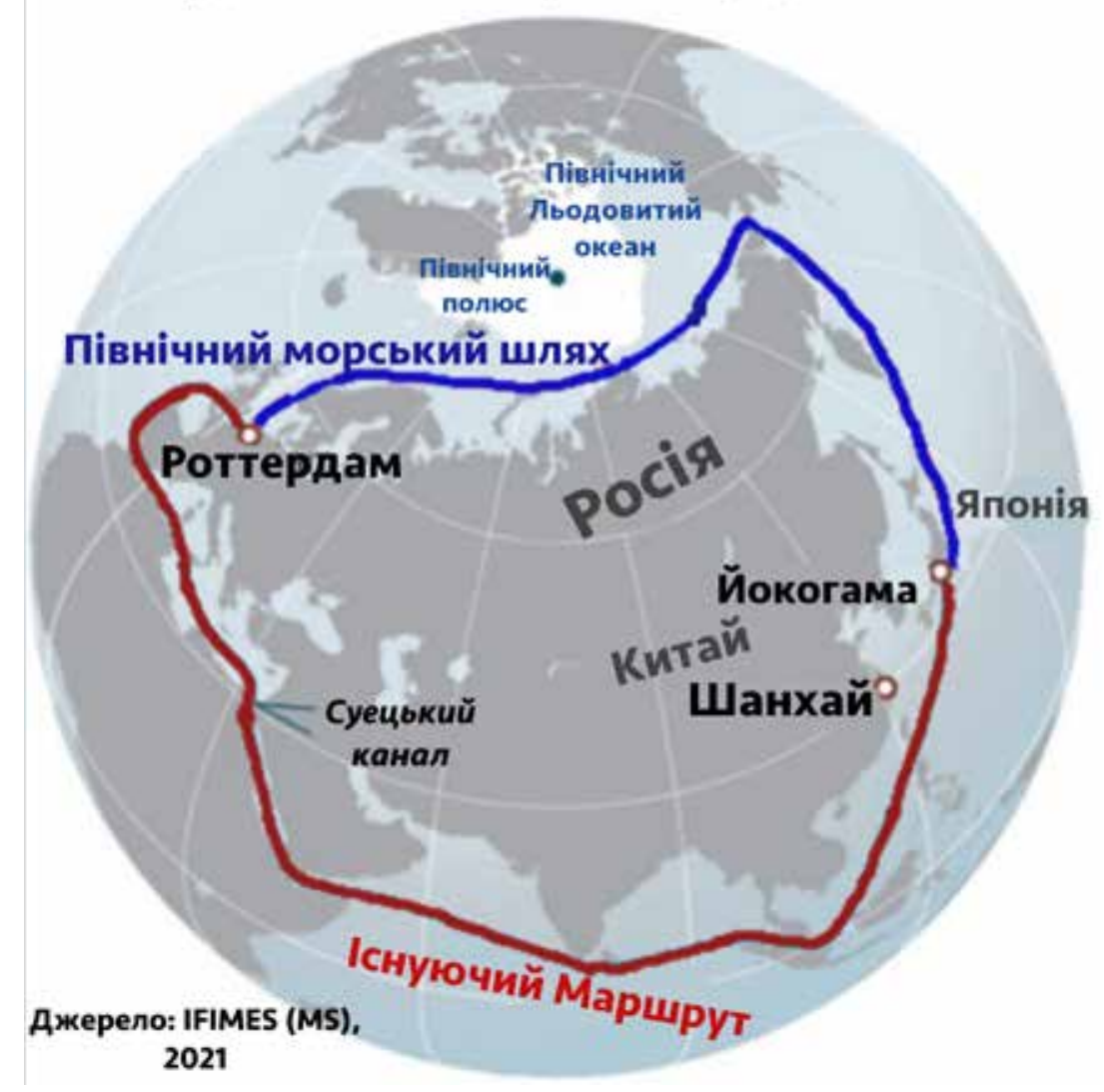

Мапа 2. Північне судноплавство.

Переваги транспортного шляху через Арктику.

Джерело: створена автором дослідження (Міжнародній інститут IFIMES), 2021 p.

\section{ЛІТЕРАТУРА}

Amelang S. Europe vies with China for clean hydrogen superpower status. China Dialogue : медіаплатформа. 29.07.2020. URL: https:/chinadialogue.net/ en/energy/europe-vies-with-china-for-clean-hydrogen-superpower-status/ (дата звернення: 29.07.2021).

Bajrektarevic A.H. Opening Up the Arctic Frontier. An Excerpt from Arctic and Antarctic: Two Poles - Different Scores. Wörterbuch der Wirtschaftswissenschaften : онлайн-журнал. 01.09.2010. URL: http://www.odww.de/index.php?navID=200 \&uid=507 (дата звернення: 25.12.2020). 
Bernadaux Ch. The Greening of Eurasia. The Diplomat Magazine : онлайнжурнал. 06.06.2021. URL: https://diplomatmagazine.eu/2021/06/06/the-greeningof-eurasia/ (дата звернення: 29.07.2021).

Bethany A.-E. China's continent spanning trains are running half-empty. The Foreign Policy : онлайн-журнал. 06.05.2017. URL: http://foreignpolicy. com/2017/06/05/chinas-continent-span-\%20ning-trains-are-running-half-emptyone-belt-one-road-bri/ (дата звернення: 25.12.2020).

Campbell C. China Is Bankrolling Green Energy Projects Around the World. “The Time : онлайн-журнал. 01.11.2019. URL: https://time.com/5714267/chinagreen-energy/ (дата звернення: 28.07.2021).

Cooper B. China's 14'th Five-Year Plan (2021-2025) Report. 38im "Hill + Knowton Strategies”. 01.04.2021. URL: https://www.hkstrategies.com/en/chinas14th-five-year-plan-2021-2025-report/ (дата звернення: 28.07.2021).

Cooper B. China's 2021 Two Sessions. 36im "Hill + Knowton Strategies". 09.03.2021. URL: https://www.hkstrategies.com/en/chinas-2021-two-sessions/ (дата звернення: 29.07.2021).

DEFRA. Global CO2 emissions. Департамент з навколишнього середовища, продовольства та сільських справ : офіційний сайт. 28.05.2012. URL: https:// www.gov.uk/government/uploads/system/uploads/attachment_data/file/69568/\%20 pb13792-emission-factor-methodology-paper-120706.pdf (дата звернення: 25.12.2020).

Егорова И. Китайский Шёлковый путь протянулся до Беларуси: что нас ждёт, кроме экологических бед? Зелений Портал : медіаплатформа. 16.01.2017. URL: $\quad$ https://greenbelarus.info/articles/16-01-2017/kitayskiy-shyolkovyy-putprotyanulsya-do-belarusi-chto-nas-zhdyot-krome (дата звернення: 04.07.2021).

An EU-wide assessment of National Energy and Climate Plans. Driving forward the green transition and promoting economic recovery through integrated energy and climate planning / European Commission. Oфiuійний сайm Свропейської комісії. 17.09.2020. URL: https://eur-lex.europa.eu/legal-content/EN/TXT/ PDF/?uri=CELEX:52020DC0564 (дата звернення: 29.12.2020).

Feng H. Can Chinese aid steer Asia toward clean energy? China Dialogue : мeдіаплатформа. 29.11.2019. URL: https://chinadialogue.net/en/energy/11699-canchinese-aid-steer-asia-toward-clean-energy/ (дата звернення: 01.08.2021).

Baiyu G. China should set up a carbon cap' - Zou Ji on the next national energy targets. China Dialogue : медіаплатформа. 02.07.2020. URL: https:// chinadialogue.net/en/energy/china-should-set-up-a-carbon-cap-zou-ji-on-the-nextnational-energy-targets/ (дата звернення: 01.08.2021).

Grünberg N., Brussee V. China's 14'th Five-Year Plan - strengthening the domestic base to become a superpower. Аналітичний центр "MERICS". 09.04.2021. URL: https://merics.org/en/short-analysis/chinas-14th-five-year-planstrengthening-domestic-base-become-superpower (дата звернення: 01.08.2021).

Huaxia. China to increase non-fossil fuels' share in primary energy consumption to around 25 pct by 2030: Xi. Інформаиійне агентство “Хіпһиа". 12.12.2020. URL: http://www.xinhuanet.com/english/2020-12/12/c_139584739.htm (дата звернення: 11.08.2021).

China's Energy Law Could Help Address The Belt And Road's Climate Impact. Міжнародний центр зі сталого вуглецю (ICSC). 30.07.2020. URL: https://www. 
sustainable-carbon.org/chinas-energy-law-could-help-address-the-belt-and-roadsclimate-impact/ (дата звернення: 11.08.2021).

The White Book on Arctic Policy / Information Office of the State Council of the People's Republic of China. Інформаційний офіс державної ради Китайської Народної Республіки. 26.01.2018. URL: https://www.yidaiyilu.gov.cn/zchj/ zcfg/45994.htm (дата звернення: 05.01.2019).

Jingjing Zh., Wang W. China's energy law could help address the Belt and Road's climate impact? China Dialogue : медіаплатформа. 22.06.2020. URL: https:// chinadialogue.net/en/energy/chinas-energy-law-could-help-address-the-belt-androads-climate-impact/ (дата звернення: 28.07.2021).

Mathews J.A. The greening of China's industrial strategy. China Dialogue : медіаплатформа. 22.05.2020. URL: https://www.eco-business.com/news/the-greeningof-chinas-industrial-strategy/ (дата звернення: 28.07.2021).

Mathews J.A., Hao Tan. Economics: Manufacture renewables to build energy security. Nature : медіаплатформа. 10.09.2014. URL: https:/www.nature.com/ articles/513166а (дата звернення: 28.07.2021).

Pamlin D. Beijing's plan shows path to the future. China Daily : новинний портал. 29.04.2016. URL: https:/www.chinadaily.com.cn/a/201604/29/ WS5a2b8271a310eefe3e9a0b6d.html (дата звернення: 28.07.2021).

Smotrytska M. China in Europe: Hit the (Belt and) Road Jack. Vision \& Global Trends : медіаплатформа. 11.09.2020. URL: https://www.vision-gt.eu/ news/cooperation/china-in-europe-hit-the-belt-and-road-jack/ (дата звернення: 03.08.2021).

Smotrytska M. EU logistics in the BRI maps: Synergy of BRI and TEN-T. Modern Diplomacy EU : інтернет-журнал. URL: https://moderndiplomacy.eu/2020/09/10/ eu-logistics-in-the-bri-maps-synergy-of-bri-and-ten-t/ (дата звернення: 09.08.2021).

Smotrytska M. European logistics hubs of Belt and Road Initiative. Aftermath of the BRI implementation in CEEC. Звіт Міжнародного інституту близькосхідних і Балканських досліджень, Департамент стратегічних досліджень по Aзї (IFIMES). 29.11.2020. URL: https://www.ifimes.org/en/researches/europeanlogistics-hubs-of-belt-and-road-initiative-aftermath-of-the-bri-implementation-inсеес/4697 (дата звернення: 03.08. 2021).

Smotrytska M. IFIMES for the Global Greening Economy (A Brief Impact Study). Звіт Міжнародного інституту близькосхідних і Балканських досліджень, Департамент стратегічних досліджень по Азї (IFIMES). 08.02.2021. URL: https://www.ifimes.org/en/researches/ifimes-for-the-globalgreening-economy-a-brief-impact-study/4731?page $=3$ (дата звернення: 03.08.2021).

Smotrytska M., Bajrektarevic A.H. Global Greening Economy (A Brief Impact Study). China News : media platform. 19.02.2021. URL: https://chinanews.net. au/2021/02/19/global-greening-economy-a-brief-impact-study/ (дата звернення: 11.08.2021).

Sun Wei. China and UK work on Green Belt and Road Initiative. The Global Times : онлайн-журнал. 12.12.2019. URL: https://www.globaltimes.cn/content/ 1173367.shtml, (дата звернення: 21.07.2021). 
Can Chinese aid go green? The Daily Star : медіапортал. Bangladesh. URL: https://www.thedailystar.net/environment-climate-action-0/news/can-chinese-aidgo-green-1835197 (дата звернення: 28.07.2021).

Suez Canal Maintained Volumes in 2020 and Extends Incentives for 2021 : доповідь. The Maritime Executive : аналітичний центр. 04.01.2021. URL: https:// maritime-executive.com/article/suez-canal-maintained-volumes-in-2020-andextends-incentives-for-2021 (дата звернення: 09.07.2021).

Treyer S. Greening the Belt and Road Initiative: recent advances in assessing the scale of the challenge, the obstacles and the tools for action. Онлайн-платформа аналітичного иентру “IDDRI". 23.09.2019. URL: https://www.iddri. org/en/publications-and-events/blog-post/greening-belt-and-road-initiative-recentadvances-assessing-scale (дата звернення: 08.07.2021).

Vinokurov E. Silk Road Transport Corridors: Assessment of Trans-EAEU Freight Traffic Growth Potential : звіт Центру інтеграційних досліджень САБР, 12.04.2018. URL: https://eabr.org/en/analytics/integration-research/cii-reports/ silk-road-transport-corridors-assessment-of-trans-eaeu-freight-traffic-growthpotential-/ (дата звернення: 25.12.2020).

Waldholz R. Hopes for EU-China climate deal centre on green recovery. Journalism for the energy transition : медіаплатформа. 18.06.2020. URL: https:// www.cleanenergywire.org/news/hopes-eu-china-climate-deal-centre-greenrecovery (дата звернення: 01.08.2021).

Yun Feng Y. China Sets 15\% Non-fossil Energy Consumption Target by 2020 : звіт Центру досліджень “ICIS Research Center". 01.20.2017. URL: https://www. icis.com/explore/resources/news/2017/01/20/10071365/china-sets-15-non-fossilenergy-consumption-target-by-2020/ (дата звернення: 05.01.2019).

\section{REFERENCES}

Amelang S.(2020), "Europe vies with China for clean hydrogen superpower status", "China Dialogue" media platform, available at: https://chinadialogue. net/en/energy/europe-vies-with-china-for-clean-hydrogen-superpower-status/ (accessed: 29 July 2021) (In English).

Bajrektarevic A.H. (2010), "Opening Up the Arctic Frontier. An Excerpt from Arctic and Antarctic: Two Poles - Different Scores", "Wörterbuch der Wirtschaftswissenschaften" online journal, available at: http://www.odww.de/ index.php?navID=200\&uid=507 (accessed: 25 December 2020) (In English).

Bernadaux Ch. (2021), “The Greening of Eurasia”, The Diplomat Magazine, available at: https://diplomatmagazine.eu/2021/06/06/the-greening-of-eurasia (accessed: 29 July 2021) (In English).

Bethany A.-E. (2017), "China's continent spanning trains are running half-empty", "The Foreign Policy" Journal, available at: http://foreignpolicy.com/2017/06/05/ chinas-continent-span-\%20ning-trains-are-running-half-empty-one-belt-one-roadbri/ (accessed: 25 December 2020) (In English).

Campbell C. (2019), "China Is Bankrolling Green Energy Projects Around the World", "The Time" Journal, available at: https://time.com/5714267/china-greenenergy/ (accessed 28 July 2021) (In English). 
Cooper B. (2021a), "China's 14th Five-Year Plan (2021-2025) Report", "Hill + Knowton Strategies" Reports, available at: https://www.hkstrategies.com/en/chinas14th-five-year-plan-2021-2025-report/ (accessed July 2021) (In English).

Cooper B. (2021b), "China's 2021 Two Sessions", "Hill + Knowton Strategies" Reports, available at: https://www.hkstrategies.com/en/chinas-2021-two-sessions/ (accessed 29 July 2021) (In English).

DEFRA (2012), "Global CO2 emissions", "Department for Environment, Food and Rural Affairs" official website, available at: https://www.gov.uk/government/ uploads/system/uploads/attachment_data/file/69568/\%20pb13792-emission-factormethodology-paper-120706.pdf (accessed: 25 December 2020) (In English).

Egorova I. (2017), "Kitayskiy Shëlkovyy put' protyanulsya do Belarusi: chto nas zhdët, krome ekologicheskikh bed?", "Zelyanyi portal" media platform, available at: https:/greenbelarus.info/articles/16-01-2017/kitayskiy-shyolkovyyput-protyanulsya-do-belarusi-chto-nas-zhdyot-krome (accessed: 04 July 2021) (In Russian).

European Commission (2020), “An EU-wide assessment of National Energy and Climate Plans. Driving forward the green transition and promoting economic recovery through integrated energy and climate planning", European Commission official website, available at: https:/eur-lex.europa.eu/legal-content/EN/TXT/ PDF/?uri=CELEX:52020DC0564 (accessed: 29 December 2020) (In English).

Feng Hao (2019), "Can Chinese aid steer Asia toward clean energy?", China Dialogue media platform, available at: https://chinadialogue.net/en/energy/11699can-chinese-aid-steer-asia-toward-clean-energy/ (accessed: 01 August 2021) (In English).

Gao Baiyu (2020), "China should set up a carbon cap' - Zou Ji on the next national energy targets", "China Dialogue" media platform, available at: https:// chinadialogue.net/en/energy/china-should-set-up-a-carbon-cap-zou-ji-on-the-nextnational-energy-targets/ (accessed: 01 August 2021) (In English).

Grünberg N. and Brussee V. (2021), "China's 14th Five-Year Plan - strengthening the domestic base to become a superpower", "MERICS" Analysis, available at: https://merics.org/en/short-analysis/chinas-14th-five-year-plan-strengtheningdomestic-base-become-superpower (accessed: 01 August 2021) (In English).

Huaxia (2020), "China to increase non-fossil fuels" share in primary energy consumption to around 25 pct by 2030: Xi", "Xinhua" News agency, 12.12.2020, available at: http://www.xinhuanet.com/english/2020-12/12/c_139584739.htm (accessed : 11 August 2021) (In English).

ICSC (2020), "China's Energy Law Could Help Address the Belt and Road's Climate Impact", International Center For Sustainable Carbon, available at: https:// www.sustainable-carbon.org/chinas-energy-law-could-help-address-the-belt-androads-climate-impact/ (accessed: 11 August 2021) (In English).

IOSC (2018), "The White Book on Arctic Policy", "Information Office of the State Council of the People's Republic of China" official website, available at: https://www. yidaiyilu.gov.cn/zchj/zcfg/45994.htm (accessed: 05 January 2019) (In Chinese).

Jingjing Zh. and Wang W. (2020), "China's energy law could help address the Belt and Road's climate impact?", "China Dialogue" media platform, available at: https://chinadialogue.net/en/energy/chinas-energy-law-could-help-addressthe-belt-and-roads-climate-impact/ (accessed: 28 July 2021) (In English). 
Mathews J.A. (2020), "The greening of China's industrial strategy”, "China Dialogue" media platform, available at: https://www.eco-business.com/news/thegreening-of-chinas-industrial-strategy/ (accessed: 28 July 2021) (In English).

Mathews J.A. and Hao Tan (2014), "Economics: Manufacture renewables to build energy security", "Nature" media platform, available at: https://www.nature. com/articles/513166a (accessed: 28 July 2021) (In English).

Pamlin D. (2016), "Beijing's plan shows path to the future", "China Daily" news portal, available at: https://www.chinadaily.com.cn/a/201604/29/ WS5a2b8271a310eefe3e9a0b6d.html (accessed: 29 July 2021) (In English).

Smotrytska M. (2020a), "China in Europe: Hit the (Belt and) Road Jack", "Vision \& Global Trends" Platform, available at: https://www.vision-gt.eu/news/ cooperation/china-in-europe-hit-the-belt-and-road-jack/ (accessed: 03 August 2021) (In English).

Smotrytska M. (2020b), "EU logistics in the BRI maps : Synergy of BRI and TEN-T", "Modern Diplomacy EU" online magazine, available at: https:// moderndiplomacy.eu/2020/09/10/eu-logistics-in-the-bri-maps-synergy-of-bri-andten-t/ (accessed: 09 August 2021) (In English).

Smotrytska M. (2020c), "European logistics hubs of Belt and Road Initiative. Aftermath of the BRI implementation in CEEC", "International Institute for Middle East and Balkan Studies, Department for Strategic Studies on Asia (IFIMES)" Reports, available at: https://www.ifimes.org/en/researches/european-logisticshubs-of-belt-and-road-initiative-aftermath-of-the-bri-implementation-in-ceec/4697 (accessed: 03 August 2021) (In English).

Smotrytska M. (2021), "IFIMES for the Global Greening Economy (A Brief Impact Study)", "International Institute for Middle East and Balkan Studies, Department for Strategic Studies on Asia (IFIMES)" Reports, available at: https:// www.ifimes.org/en/researches/ifimes-for-the-global-greening-economy-a-briefimpact-study/4731?page=3 (accessed: 03 August 2021) (In English).

Smotrytska M. and Bajrektarevic A.H., Global Greening Economy (A Brief Impact Study), "China News" media platform, 19.02.2021, available at: https:// chinanews.net.au/2021/02/19/global-greening-economy-a-brief-impact-study/ (accessed: 11 August 2021) (In English).

Sun Wei (2019), "China and UK work on Green Belt and Road Initiative", "The Global Times" Journal, available at: https://www.globaltimes.cn/content/1173367. shtml (accessed: 21 July 2021) (In English).

TDS (2019), "Can Chinese aid go green?", "The Daily Star” media portal, Bangladesh, available at: https://www.thedailystar.net/environment-climateaction-0/news/can-chinese-aid-go-green-1835197 (accessed: 28 July 2021) (In English).

TME (2021), "Suez Canal Maintained Volumes in 2020 and Extends Incentives for 2021", "The Maritime Executive" Researches, available at: https://maritimeexecutive.com/article/suez-canal-maintained-volumes-in-2020-and-extendsincentives-for-2021 (accessed: 09 July 2021) (In English).

Treyer S. (2019), "Greening the Belt and Road Initiative: recent advances in assessing the scale of the challenge, the obstacles and the tools for action", "IDDRI" think-tank online platform, available at: https:/www.iddri.org/en/ 
publications-and-events/blog-post/greening-belt-and-road-initiative-recentadvances-assessing-scale (accessed: 8 July 2021) (In English).

Vinokurov E. (2018), "Silk Road Transport Corridors: Assessment of TransEAEU Freight Traffic Growth Potential", "EADB Center for Integration Studies" Report, available at: https://eabr.org/en/analytics/integration-research/cii-reports/ silk-road-transport-corridors-assessment-of-trans-eaeu-freight-traffic-growthpotential-/ (accessed: 25 December 2020) (In English).

Waldholz R. (2020), "Hopes for EU-China climate deal centre on green recovery", "Journalism for the energy transition" media platform, available at: https://www. cleanenergywire.org/news/hopes-eu-china-climate-deal-centre-green-recovery (accessed: 01 August 2021) (In English).

Yun Feng Yu (2017), "China Sets 15\% Non-fossil Energy Consumption Target by 2020", "ICIS Research Center" website, available at: https://www.icis.com/ explore/resources/news/2017/01/20/10071365/china-sets-15-non-fossil-energyconsumption-target-by-2020/ (accessed: 05 January 2019) (In English).

Стаття надійшла до редакиії 10.10.2021 